\title{
Análise exegética do Salmo 84
}

\author{
Orientador: Prof. Leonardo Agostini Fernandes \\ Pesquisadora: Fátima Regina Pereira Pinto \\ Fonte: $\mathrm{CNPq}$
}

\section{Introdução}

O S1 84 oferece uma belíssima moldura sobre a experiência que o ser humano realiza na sua peregrinação ao encontro de Deus e as consequências morais que dela derivam para a sua vida pessoal e para toda a comunidade de fé.

No S1 84 aparece apenas a voz de um interlocutor que se dirige a Deus em oração exclamativa e contemplativa, mas o protagonismo do texto é de Deus. Através de sua locução o orante fala com Deus, fala sobre Deus e reflete sobre os fatos da vida que o cerca.

Para o orante, Deus é o Senhor da História (cf. Is 45,10; Jr 27,5) e criou o mundo como um lugar acolhedor e dotado de todas as necessidades que favorecem a fecundação da vida. Essa afirmação deve ser entendida à luz dos acontecimentos descritos no Antigo Testamento, pelo qual se narra a experiência política e religiosa de Israel, povo que Deus elegeu, como sua pessoal propriedade (Ex 19,5-6).

A fé de Israel está integrada na promessa e na aliança que Deus fez com seu povo (Gn 22,16-18) e de fato, Deus vem cumprindo na história tudo aquilo que prometeu à criatura humana. Portanto, o orante tem certeza que Deus escuta com atenção e interesse as inquietudes humanas e age em favor do bem comum. A confiança de ser acolhido por Deus impele o orante para um caminho de peregrinação, cujo objetivo não é só o de apresentar a entrega de sua oração sincera, como também oferecer a sua vida em obediência ao seu Deus. 


\section{Objetivos}

O objetivo geral é duplo: conhecer e saber aplicar os instrumentos metodológicos e exegéticos disponíveis para uma correta análise do texto, propiciando o passo-a-passo, componente essencial para o desenvolvimento e conclusão dessa pesquisa.

Objetivos secundários: fazer o levantamento bibliográfico, selecionar e analisar o material. Passos importantes na primeira etapa da pesquisa, pois impôs a decisão de escolher os materiais necessários que contemplassem o objeto de estudo, cujos critérios e argumentos, a pesquisadora pudesse encontrar cognação para auxiliar na exposição de suas ideias.

Resultam desses objetivos a identificação do possível sentido literal do S1 84, isto é, aquele desejado pelo autor, segundo o contexto social, cultural e religioso de sua época. Por meio disso, pode-se alcançar a atualização da mensagem para o ouvinte-leitor contemporâneo, a fim de alcançar, na medida do possível, o aporte necessário quanto ao desafio de refletir o texto e torná-lo inteligível e provocativo.

Em última instancia, e não menos importante, está a finalidade de cooperar com a reflexão e o saber teológicos, dentro da linha de pesquisa do orientador, através de um resultado descritivo, analítico e exegético do Sl 84. 